\title{
Development and characterization of microsatellite loci for Cedrela fissilis Vell (Meliaceae), an endangered tropical tree species
}

\author{
By F. B. Gandara ${ }^{1)}$, E. V. TAmbarussi ${ }^{2)}$, A. M. SebbenN ${ }^{3), *)}$, E. M. Ferraz ${ }^{1)}$, \\ M. A. Moreno $^{1)}$, A. Y. Ciampi ${ }^{4)}$, R. P. Vianello ${ }^{5)}$, D. Grattapaglia ${ }^{4)}$ and P. Y. Kageyama ${ }^{1)}$
}

(Received 13 ${ }^{\text {th }}$ March 2015)

\begin{abstract}
The timber of the Neotropical tree Cedrela fissilis is used in construction, shipbuilding, carpentry and for medical purposes. In this study, polymorphic microsatellite (SSR) markers derived from an enriched genomic library were characterized using 120 adult trees from four different $C$. fissilis populations. No substantial genotypic linkage disequilibrium was detected among all possible pairs of SSR loci. The number of alleles per locus ranged from 2 to 20 , the average allele number ranged from 8 to 9.7 , depending on the population. The observed heterozygosity among the different SSR loci varied from 0.0 to 1.00 , the expected heterozygosity varied from 0.07 to 0.95 On the population level, the average observed and expected heterozygosities ranged from 0.50 to 0.63 and from 0.64 to 0.70 , respectively. The average fixation index among populations ranged from 0.09 to 0.24 . Thus, the SSR loci revealed high polymorphism rates and can be used to study the genetic diversity,structure, mating system, and gene flow in C. fissilis.
\end{abstract}

Key words: Cedar; Genetic diversity; Microsatellite markers; Neotropical tree species.

\section{Introduction}

Studies on population genetics can be helpful to design effective in situ management plans for tree species, in particular for those species which are subjected to forest fragmentation and logging. The Meliaceae family includes six species of the genus Cedrela, which are distributed from southern Mexico to northern Argentina (STYLES, 1981). Three of the species, Cedrela fissilis Vell, Cedrela odorata L. and Cedrela lilloi C. DC.,

\footnotetext{
1) Escola Superior de Agricultura "Luiz de Queiroz," Universidade de São Paulo, Av. Pádua Dias, 11, Caixa Postal 9, Piracicaba, SP, CEP: 13418-900, Brazil.

$\left.{ }^{2}\right)$ Universidade Federal de São Carlos, Departamento de Biologia, Rod. João Leme dos Santos, Km 110, Sorocaba, SP, CEP: 18052-780, Brazil.

3) Instituto Florestal de São Paulo, CP 1322, São Paulo, SP, CEP: 01059-970, Brazil.

4) Empresa Brasileira de Pesquisa Agropecuária, Embrapa Recursos Genéticos e Biotecnologia. Estação Parque Biológico SAIN Final W5 norte, Brasilia, DF, 70770-900, Brazil.

5) Rosana Pereira Vianello, Empresa Brasileira de Pesquisa Agropecuária, Centro Nacional de Pesquisa de Arroz e Feijão. Rodovia Goiânia/Nova Veneza Km12. Laboratório de Biotecnologia. CP: 179, Goiania, GO, CEP: 74001-179, Brazil.

*) Corresponding author: AleXandre Magno SebBenn. Instituto Florestal de São Paulo, CP 1322, São Paulo, SP, CEP: 01059-970, Brazil, Phone: +551934351681. E-mail: alexandresebbenn@ yahoo.com.br.
}

are native to Brazil. All of them arelisted as endangered species (IUCN, 2012).

C. fissilis is widely distributed in Brazil (ranging from latitudes $1^{\circ} \mathrm{S}$ (Pará State) to $33^{\circ} \mathrm{S}$ (Rio Grande do Sul State). It has a wide range of uses. Roundwood or sawnwood can be used for different construction purposes like e.g. ship- and aerospace-building, furniture making and the production of musical instruments. For the use as firewood, the wood is considered of good quality, but its high market value makes it inappropriate for this purpose (CARVALHO, 1994). It is also used in medicine to combat fever, wounds and ulcers. Based on its wide range of utilization, populations of this species have decreased. Strategies for in and ex situ conservation of the remaining populations are necessary (KAGEYAMA et al., 2003; KAGEYAMA et al., 2014; SoldATI et al., 2014).

Studies in populations of endangered tree species are necessary, since forest fragmentation can lead to species extinction or loss of tree populations. Microsatellite markers are well-suited for the use in in population genetic studies (SlatKIN, 1995), due to high polymorphism rates. In this study, microsatellite markers were developed for $C$. fissilis and can be used for commercial and conservation interests.

\section{Materials and Methods \\ Sampling of plant material}

Sampling took place in four large areas, covering more than 750 ha of well-preserved mature forests with significant natural populations of $C$. fissilis. The four studied areas are located in the municipalities of Pidamonhangaba (VP) $\left(22^{\circ} 46^{\prime} \mathrm{S}, 45^{\circ} 27^{\prime} \mathrm{W}, 1,200\right.$ ha), Sete Barras

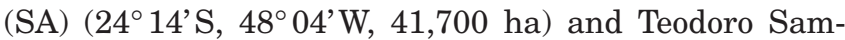
paio (MD) $\left(22^{\circ} 35^{\prime} \mathrm{S}, 52^{\circ} 12^{\prime} \mathrm{W}, 33,800 \mathrm{ha}\right)$ in the state of São Paulo and in the municipality of Ilhota (MB) $\left(26^{\circ} 35^{\prime} \mathrm{S}, 48^{\circ} 48^{\prime} \mathrm{W}, 750\right.$ ha) in the state of Santa Catarina. Sampling areas were chosen by their regional representation, preservation status, accessibility and available infrastructure. All areas consist out of forests that are situated in the Atlantic Forest Biome and represent the most threatened vegetation type in Brazil. 30 adjacent - and thus representing a continuous spatial sample - trees per population were chosen for sampling. Only adult individuals that occupied the canopy and/or showed signs of reproduction (presence of flowers or fruits) were sampled.

\section{Microsatellite development}

Total genomic DNA was extracted from fresh leaves from a single $C$. fissilis tree collected on Campus of 
Table 1. - Microsatellite primers developed for Cedrela fissilis. The forward (F) and reverse (R) sequence, Repeat motif, size of the original fragment (bp) and annealing temperature $\left(\mathrm{Ta}^{\circ} \mathrm{C}\right)$ are shown for each primer pair.

\begin{tabular}{|c|c|c|c|c|}
\hline Locus & Primer sequence & Repeat motif & Size & $\Gamma^{a}\left({ }^{\circ} \mathrm{C}\right)$ \\
\hline \multirow[t]{2}{*}{$\mathrm{Cl}: 09$} & l: 'I"IG']CCACGGICIAAA I"TCCT"T & $(\operatorname{ga})_{9}$ & $248 \quad 258$ & 54 \\
\hline & R: TCCATAACCCGACCCATGA & & & \\
\hline \multirow[t]{2}{*}{$C F 26$} & F:CCAА & $(g a)_{19}$ & 146 & 56 \\
\hline & R: GITCTGCTCATCGAAGG & & & \\
\hline \multirow[t]{2}{*}{ C1:32 } & I: GTACAC[GCC]"IAGTCCA & $(\mathrm{Ct})_{32}$ & $136-144$ & 46 \\
\hline & R: ATTGAAAGACATCAGGC & & & \\
\hline \multirow[t]{2}{*}{ Cl:34 } & l:GITGGCAGCATGAITACC & $(g a)_{20}$ & 128 & 56 \\
\hline & R: GAAGACTGTGTCTCTGAGTGG & & & \\
\hline \multirow[t]{2}{*}{$C F 63$} & F: CCCACAAATTAACATCCCAA & $(\mathrm{ga})_{17}$ & $128-172$ & 54 \\
\hline & R: CAGCOTAGAGCCGAATTCA & & & \\
\hline \multirow[t]{2}{*}{$\cos 6 \mathrm{~A}^{*}$} & I: CAGCAGTTCIGAAACAGIAA & & $118-170$ & 56 \\
\hline & R: ATTCAGCAACTTGAGAGC & $(g a) / 9$ & & \\
\hline \multirow[t]{2}{*}{ CF $66 \mathrm{~B}^{*}$} & 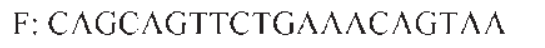 & $(9 a)_{19}$ & 202 & 56 \\
\hline & R: $\triangle T T C \wedge G C \wedge \Lambda C T T G \Lambda G \wedge G C$ & & & \\
\hline \multirow[t]{2}{*}{$C F 78$} & F: GCCACAATATCTACTCTCAG & $(\mathrm{cl})_{17}$ & $122-168$ & 56 \\
\hline & R: Gl"ITCCICICI"]CGG]"l"I & & & \\
\hline \multirow[t]{2}{*}{ C.183 } & I: ACCAI"ICGAGCCCCACIACA & $(t c)_{20}$ & $312-328$ & 54 \\
\hline & R: GCCAAGGCAACCGAATCA & & & \\
\hline
\end{tabular}

* Two different loci amplified by the same primer.

"Luiz de Queiroz" College of Agriculture (University of São Paulo, Esalq/USP) using the protocol described by Doyle and DoYle (1987). The genomic DNA was digested using the restriction endonuclease Sau3AI (New England Biolabs, Ipswich, Massachusetts, USA) and separated on an agarose gel. DNA fragments between 280 and $600 \mathrm{bp}$ were transferred to a cellulose membrane (NA-45). The library was enriched in microsatellite fragments using (AG/TC) ${ }_{13}$ motifs linked to biotin. The enriched fragments were cloned into the pGEM-T Easy Vector (Promega Corporation, Madison, Wisconsin, USA), the ligation products were used to transform Epicurian Coli XL1-Blue Escherichia coli-competent cells (Stratagene, Agilent Technologies, Santa Clara, California, USA). Transformed cells were cultivated on agar plates containing $100 \mu \mathrm{g} / \mathrm{mL}$ ampicillin, $50 \mu \mathrm{g} / \mathrm{mL}$ $\mathrm{X}$-galactosidase, and isopropyl $\beta$-D-1-thiogalactopyranoside (IPTG). Single white colonies were selected and stored at $-80^{\circ} \mathrm{C}$. A total of 884 recombinant colonies were obtained. Extraction of DNA from plasmid was carried out using the Wizard Miniprep system (Promega). All 884 recombinant clones were sequenced using the primers $R s a \quad 21$ (5'-TCTTGCTTACGCGTGGACTA-3') and $R s a 25$ (5'-AGTCCACGCGTAAGCAAGAGCACA-3') and the the BigDye Terminator version 3.1 cycle sequencing kit (Applied Biosystems).

Sequencing was performed using an ABI 377 automated sequencer (Applied Biosystems, Foster City, California, USA) The program VecScreen was used to remove vector segments from each of the sequences (http:// www.ncbi.nlm.nih.gov/VecScreen/VecScreen.html). Nine SSR loci, discovered within the sequenced clones, were selected for primer design. The selection criteria were high sequence quality and a minimum of 6 SSR motive repeats. Primer design was executed using the software Primer3 v0.4.0 (http://bioinfo.ut.ee/primer3-0.4.0) according to the following criteria: annealing temperature ranging from $52-60^{\circ} \mathrm{C}$ and $\mathrm{GC}$ content between 40 and $60 \%$. Each primer pair was designed to amplify a fragment of 150 to $300 \mathrm{bp}$ (Table 1).

\section{Marker analysis}

For all adult trees, DNA was extracted from $100 \mathrm{mg}$ of fresh leaves using the method of Doyle and Doyle (1987). All 8 microsatellite loci (Table 1) were amplified and scored in all 120 sampled $C$. fissilis individuals following the protocols of RITTER et al. (2011) and CRESTE et al. (2001). Allele scoring was carried out using the 10 bp DNA Ladder (Invitrogen) as size standard.

\section{Data analysis}

Genetic diversity was characterized as a mean across all loci using the following indices: total number of alleles $(k)$, observed heterozygosity $\left(H_{o}\right)$ and expected heterozygosity under Hardy-Weinberg equilibrium $\left(H_{e}\right)$. To check for potential inbreeding $(F)$, we used the within population fixation index. The statistical significance of $F$ values was tested by permuting alleles among individuals, associated to a Bonferroni correction for multiple tests $(95 \%, \alpha=0.05)$. All analyses, including genotypic linkage disequilibrium, were performed using the FSTAT program (GoudET, 1995).

\section{Results}

Eight hundred and eighty-four recombinant colonies of the $C$. fissilis genomic library were analyzed during this study. Microsatellites were found in 168 (19\%) of the recombinant clones, demonstrating a low efficiency of the library enrichment. A significant genotypic linkage disequilibrium was detected for only two pairs of loci (CF26xCF66B and CF26xCF83) from the VP popu- 
Table 2. - $\mathrm{P}$ value results of the estimates of genotypic disequilibrium between pairwise loci for four Cedrela fissilis populations. Adjusted P-value for 5\% nominal level of Bonferroni correction is 0.000347 .

\begin{tabular}{|c|c|c|c|c|}
\hline Pairwise loci & $\begin{array}{l}\text { Ilhotat } \\
\text { (MB) }\end{array}$ & $\begin{array}{l}\text { Teodoro Sampato } \\
\text { (MD) }\end{array}$ & $\begin{array}{l}\text { Sete Barras } \\
\text { (SA) }\end{array}$ & $\begin{array}{c}\text { Pindamonlangaba } \\
\text { (VP) }\end{array}$ \\
\hline CF09 X CF26 & 0.92847 & 0.16667 & 0.64583 & 0.15729 \\
\hline CF09 XCF32 & 0.30625 & 0.31944 & 0.3375 & 0.42049 \\
\hline CFO9 XCF34 & 0.86701 & 0.30625 & 0.22847 & 0.62813 \\
\hline $\mathrm{CF} 09 \times \mathrm{CF} 63$ & 0.86979 & 0.73368 & 0.12674 & 0.40833 \\
\hline CF09 X CF66A & 0.76076 & 0.57153 & 0.30451 & 0.87708 \\
\hline $\mathrm{CF} 09 \times \mathrm{CF} 6613$ & 0.88819 & 0.90868 & 0.21736 & 0.07222 \\
\hline CF09 X CF 78 & 0.81632 & 0.62500 & 0.38194 & 0.21701 \\
\hline CF09 XCF83 & 0.73507 & 0.62188 & 0.02778 & 0.07431 \\
\hline CF26 XCF 32 & 0.11806 & 0.05243 & 1.00000 & 0.15729 \\
\hline $\mathrm{CF} 26 \times \mathrm{CF} 34$ & 0.12118 & 1.00000 & 0.22951 & 0.00417 \\
\hline $\mathrm{CF} 26 \times \mathrm{CF} 63$ & 0.06458 & 0.45799 & 0.07813 & 0.17465 \\
\hline CF26 X CF $66 \Lambda$ & 1.00000 & 1.00000 & 0.64514 & 0.06979 \\
\hline CF26 X CF66B & 0.03715 & 0.03160 & 0.90694 & $0.00035^{*}$ \\
\hline CF26 X CF78 & 1.00000 & 1.00000 & 0.45660 & 0.43438 \\
\hline CI26 XCI83 & 0.78750 & 0.08229 & 0.53056 & $0.00035^{*}$ \\
\hline $\mathrm{Cl} 32 \times \mathrm{Cr} 34$ & 0.27431 & 0.90625 & 0.33611 & 0.00208 \\
\hline CF32X CF63 & 0.52431 & 0.15451 & 0.08958 & 0.00417 \\
\hline CF $32 \times C F 66 \wedge$ & 0.80938 & 0.62431 & 0.83924 & 0.04549 \\
\hline CF32X CF66B & 0.98646 & 0.89097 & 0.44896 & 0.06181 \\
\hline CF32X CF78 & 0.72743 & 0.78889 & 0.65556 & 0.04931 \\
\hline CF32XCF83 & 0.48403 & 0.92813 & 0.43576 & 0.33021 \\
\hline $\mathrm{Cl} 34 \times \mathrm{Cr} 63$ & 1.00000 & 1.00000 & 0.08264 & 0.25347 \\
\hline CF34 X CF66A & 0.12465 & 1.00000 & 1.00000 & 0.01528 \\
\hline $\mathrm{CF} 34 \times \mathrm{CF} 66 \mathrm{~B}$ & 0.29722 & 0.13854 & 0.01806 & 0.05035 \\
\hline CF34 X CF78 & 1.00000 & 0.44306 & 0.75799 & 0.53750 \\
\hline CF34 X CF83 & 0.29583 & 0.24132 & 0.08681 & 0.48993 \\
\hline $\mathrm{Cr} 63 \times \mathrm{CF} 66 \mathrm{~A}$ & 1.00000 & 0.21424 & 0.18924 & 0.05417 \\
\hline $\mathrm{Cl} 63 \times \mathrm{CF} 66 \mathrm{~B}$ & 0.51285 & 0.87153 & 0.11042 & 0.13021 \\
\hline CF63 X CF78 & 0.26771 & 0.5441 & 0.53368 & 0.11875 \\
\hline CF63 X CF83 & 0.72326 & 0.43611 & 0.78090 & 0.18681 \\
\hline CF $66 \wedge \times$ CF66B & 1.00000 & 0.47882 & 0.53819 & 0.00764 \\
\hline CF66A X CF78 & 1.00000 & 1.00000 & 1.00000 & 0.25833 \\
\hline $\mathrm{CF} 66 \mathrm{~A} \times \mathrm{CF} 83$ & 0.16076 & 0.59063 & 0.42951 & 0.00278 \\
\hline $\mathrm{Cl} 663 \mathrm{~B} \times \mathrm{CF} 78$ & 0.64722 & 0.27326 & 0.72153 & 0.27708 \\
\hline CF66B X CF83 & 0.24931 & 0.3066 & 0.75868 & 0.00104 \\
\hline CF78 X CF83 & 0.58854 & 0.02882 & 0.19965 & 0.07674 \\
\hline
\end{tabular}

$* \mathrm{P}<0.05$.

Table 3. - Population genetic parameters calculated for nine microsatellite loci developed for $C$. fissilis: sample size for each population $(n)$, number of alleles $(k)$, expected heterozygosity $\left(H_{e}\right)$, observed heterozygosity $\left(H_{o}\right)$ and fixation index $(F)$.

\begin{tabular}{|c|c|c|c|c|c|c|c|c|c|c|c|c|c|c|c|c|}
\hline \multirow[t]{2}{*}{ l.ocus } & \multicolumn{4}{|c|}{ Ilhota $(M B)(n=30)$} & \multicolumn{4}{|c|}{$\begin{array}{c}\text { Teodoro Sampaio (MD) }(\mathrm{n}= \\
30)\end{array}$} & \multicolumn{4}{|c|}{ Sete Barras $(\mathrm{SA})(\mathrm{n}=30)$} & \multicolumn{4}{|c|}{$\begin{array}{c}\text { Pindamonhangaba }(\mathrm{n}=30) \\
\text { (VP) }\end{array}$} \\
\hline & $k$ & $H_{0}$ & $H_{i^{\prime}}$ & $F$ & $k$ & $H_{\theta}$ & $H_{f^{\prime}}$ & $F$ & $k$ & $H_{f^{\prime}}$ & $H_{e}$ & $F$ & $k$ & $H_{i}$ & $H_{s}$ & $F$ \\
\hline $\mathrm{CH} 09$ & 2 & 0.08 & 0.07 & -0.02 & 3 & 0.30 & 0.52 & 0.43 & 2 & 0.41 & 0.49 & 0.16 & 2 & 0.00 & 0.24 & $1.00^{*}$ \\
\hline $\mathrm{CF} 26$ & 16 & 0.63 & 0.93 & $0.32 *$ & 15 & 0.31 & 0.93 & $0.67^{*}$ & 9 & 0.80 & 0.89 & 0.10 & 10 & 0.52 & 0.89 & $0.42^{*}$ \\
\hline $\mathrm{CF} 32$ & 2 & 0.26 & 0.23 & -0.13 & 2 & 0.30 & 0.35 & 0.13 & 2 & 0.07 & 0.07 & $-0.02 *$ & 2 & 0.07 & 0.38 & 0.82 \\
\hline $\mathrm{CF} 34$ & 10 & 0.68 & 0.86 & 0.21 & 13 & 0.93 & 0.89 & -0.04 & 10 & 0.86 & 0.83 & -0.04 & 9 & 0.83 & 0.87 & 0.05 \\
\hline $\mathrm{CH} 63$ & 13 & 0.72 & 0.89 & 0.19 & 17 & 0.57 & 0.90 & $0.37^{*}$ & 7 & 0.85 & 0.78 & -0.09 & 12 & 0.77 & 0.86 & 0.11 \\
\hline$C F 6 \cap \Lambda$ & 14 & 0.79 & 0.89 & 0.11 & 15 & 0.87 & 0.91 & 0.05 & 20 & 1.00 & 0.95 & $-0.06^{*}$ & 15 & 0.97 & 0.91 & -0.07 \\
\hline CF 6613 & 4 & 0.41 & 0.54 & 0.25 & 6 & 0.34 & 0.34 & -0.01 & 7 & 0.52 & 0.74 & 0.30 & 8 & 0.77 & 0.79 & 0.02 \\
\hline $\mathrm{CF} 78$ & 11 & 0.78 & 0.77 & -0.01 & 12 & 0.79 & 0.81 & 0.03 & 12 & 1.00 & 0.89 & $-0.13^{*}$ & 10 & 1.00 & 0.85 & -0.18 \\
\hline CF83 & 4 & 0.14 & 0.58 & $0.75^{*}$ & 4 & 0.31 & 0.56 & $0.45^{*}$ & 4 & 0.20 & 0.67 & $0.70^{*}$ & 4 & 0.48 & 0.52 & 0.08 \\
\hline Mean & 8.4 & 0.50 & 0.64 & $0.22^{*}$ & 9.7 & 0.52 & 0.69 & $0.24 *$ & 8.1 & 0.63 & 0.70 & 0.09 & 8.0 & 0.60 & 0.70 & $0.14^{*}$ \\
\hline Total & 76 & - & - & - & 87 & - & - & - & 73 & - & - & - & 72 & - & - & - \\
\hline
\end{tabular}

$* \mathrm{P}<0.05$. 
lation (Table 2), showing that the eight loci do not seem to be genetically linked. The total number of alleles ranged from 72 to 87 depending on the population. The average number of alleles per loci ranged from 8.0 to 9.7 (Table 3). The observed heterozygosity strongly varied in the SA population (from 0.00 to 0.966 ) and the expected heterozygosity strongly varied $(0.068$ to 0.946$)$ in VP population. The average observed heterozygosity ranged from 0.449 to 0.635 and the expected heterozygosity ranged from 0.642 to 0.700 , depending on the population. The average fixation index ranged from 0.093 to 0.243 , depending on the population. It was significantly higher than zero in the MB, MD and VP populations, suggesting inbreeding.

\section{Discussion}

The development of specific microsatellite markers is fundamental for new studies in the field of population genetics and the development of conservation strategies for endangered species (KoNZEN, 2014). In this paper, we describe a set of microsatellite markers for C. fissilis. These markers will be important to study populations of C. fissilis and other species of the genus.

Few of the identified clones of the enriched genomic library were found to contain microsatellites, demonstrating a low efficiency of the library enrichment. However, a set of nine polymorphic SSR markers was obtained.

The genetic diversity of the different $C$. fissilis populations was moderate but similar to the values obtained in studies of microsatellite markers in other species of the Meliaceae family, such as Cedrela balansae $\left(H_{e}=0.643\right)$, Swietenia humilis $\left(H_{e}=0.548\right)$ and Swietenia macrophylla $\left(H_{e}=0.657\right)$, (WhITE et al., 1999; Novick et al., 2003; SolDATI et al., 2013). However, for C. fissilis, other studies have reported higher values of genetic diversity $\left(H_{e}=0.820\right)$ (KAGEYAMA et al., 2003).

Genotypic linkage disequilibrium was detected for two pairs of SSR loci within the VP population and may have occurred due to the effects of forest fragmentation, producing genetic drift. Genotypic linkage disequilibrium between pairwise loci in plants is caused by selfing, mating among relatives and bottlenecks (HARTL and Clark, 1989). A possible recent bottleneck could be a cause of genotypic disequilibrium in the studied populations.

The presented new and informative microsatellite markers can be used to investigate populations of C. fissilis for breeding, conservation and environmental reforestation plans. The markers can be used for inferring genetic diversity, mating system and gene flow in C. fissilis.

\section{Accession numbers}

The sequences were deposited in the GenBank database with the following accession numbers: KP238561 [CF09]; KP238562 [CF26]; KP238563 [CF32]; KP238564 [CF34]; KP238565 [CF63]; KP238566 [CF66A and B]; KP238567 [CF78]; KP238568 [CF83].

\section{Acknowledgements}

We thank the Cenargen (Embrapa Recursos Genéticos e Biotecnologia) for help with the lab work and Fundação de Amparo à Pesquisa do Estado de São Paulo (FAPESP 1998/2448-7) for funding this research. Alexandre Magno Sebbenn and Dario Grattapaglia are recipient of research fellowship from Conselho Nacional de Desenvolvimento Científico e Tecnológico (CNPq).

\section{References}

Carvalho, P. E. R. (1994): Espécies Florestais Brasileiras: Recomendações silviculturais, potencialidades e uso da madeira. EMBRAPA-CNPF, Brasilia, Brazil, 640p.

Creste, S., A. T. Neto and A. Figueira (2001): Detection of single sequence repeat polymorphisms in denaturing polyacrylamide sequencing gels by silver staining. Plant Molecular Biology Reporter 19: 299-306.

Doyle, J. J. and J. L. DoyLE (1987): A rapid DNA isolation procedure for small quantities of fresh leaf tissue. Phytochemistry 19: 11-15.

GoudET, J. (2002): Fstat (Version 2.9.3.2.): a computer program to calculate F-statistics. Journal of Heredity 86: $485-486$.

IUCN (2012): IUCN Red List of Threatened Species. Version 2012.2. http://www.iucnredlist.org (March 11, 2015).

Kageyama, P. Y., D. Caron, F. Gandara and J. D. SAntos (2004): Conservation of Mata Atlântica forest fragments in the State of São Paulo, Brazil. In: VINCETI, B., Amaral, W., Meilleur, B. (Eds.), Proceedings of the Symposium on Challenges in Managing Forest Genetic Resources for Livelihoods: Examples from Argentina and Brazil. International Plant Genetic Resources Institute, Rome, Italy, pp. 167-185.

Kageyama, P. Y., A. M. Sebbenn, L. A. Ribas, F. B. GandaRA, M. Castellen, M. B. Perecim and R. Vencovsky (2003): Diversidade genética em espécies arbóreas tropicais de diferentes estágios sucessionais por marcadores genéticos. Scientia Forestalis 64: 93-107.

KonZEN, E. R. (2014): Towards conservation strategies for forest tree endangered species: the meaning of population genetic statistics. Advances in Forestry Science 1: 45-51.

Ritter, L. M. O., M. M. Bajay, M. Monteiro, R. G. V. C. Souza, M. A. Moreno and P. Y. Kageyama (2011): Development of microsatellite markers for Qualea grandiflora (Vochysiaceae), a typical species of the Brazilian cerrado. American Journal of Botany 99: e97-e98 (doi: 10.3732/ajb.1100405).

SLAtKIN, M. (1995): A measure of population subdivision based on microsatellite allele frequencies. Genetics 139: 457-462.

Soldati, M. C., M. V. InZA, L. Fornes and N. ZELENER (2014): Cross transferability of SSR markers to endangered Cedrela species that grow in Argentinean subtropical forests, as a valuable tool for population genetic studies. Biochemical Systematics and Ecology $\mathbf{5 3}$ 8-16.

StYles, B. T. (1981): Swietenioideae. In: Pennington, T.D., Styles, B.T., Taylor, D.A.H. (Eds.), Meliaceae. Flora Neotropica Monograph. Botanical Garden, New York, USA, pp. 359-418. 